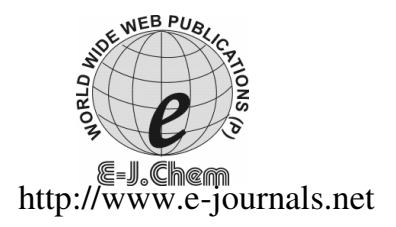

ISSN: 0973-4945; CODEN ECJHAO
E-Journal of Chemistry
2010, 7(4), 1346-1358

\title{
Adsorption Kinetics and Thermodynamics Characteristics of Expanded Graphite for Polyethylene Glycol
}

\author{
XIU-YAN PANG \\ College of Chemistry and Environmental Science, \\ Hebei University, Baoding 071002 People' Republic of China. \\ pxy833@163.com
}

Received 21 January 2010; Accepted 15 March 2010

\begin{abstract}
In the present study, expanded graphite (EG) was prepared with 50 mesh crude graphite through chemical oxidation and its adsorption kinetics and thermodynamic characteristics for polyethylene glycol (PEG) with different molecular weight (MW) in aqueous solution was investigated. We studied the influence of initial PEG concentration, temperature, $\mathrm{pH}$ and ionic strength on adsorption capacity. Langmuir constants and Gibbs free energy change $\left(\Delta \mathrm{G}^{\circ}\right)$ were calculated according to experimental data, respectively. Thermodynamic study indicates that all the equilibrium adsorbance increase with the rise in ionic strength. However, solution acidity does not have an obvious effect. Adsorption of EG for PEG with different MW is all types and PEG molecule lies flat on EG surface. Adsorption processes are all spontaneous. Kinetic studies show that the kinetic data can be delineated by pseudo second-order kinetic model. Second-order rate constants and the initial adsorption rate rise with the increasing of temperature and half-adsorption time decreases with the increasing of temperature. The adsorption activation energy of each PEG is less than $30 \mathrm{~kJ} \mathrm{~mol}^{-1}$, physical adsorption is the major mode of the overall adsorption process.
\end{abstract}

Keywords: Expanded graphite, Polyethylene glycol, Adsorption kinetics, Adsorption thermodynamics, Ionic strength.

\section{Introduction}

Polyethylene glycol (PEG) is widely applied in industries, such as medicament, metal forming, cosmetics and food. However, the wasted medicament solution may become one of the major wastewater sources in industry because the main components of the some minor additives such as PEG, which is a neutral surfactant and acts as a drug stabilizer ${ }^{1}$. The principal treatment methods of PEG wastewater are biodegradation ${ }^{2}$, chemical oxidation ${ }^{3}$, and adsorption treatment such as adsorption into activated carbon ${ }^{4}$, or hydrophobic zeolite $^{6}$. 
In wastewater treatment, it is well known that adsorption process has been considered available method for eliminating organic pollutants. In the adsorption of PEG with active carbon as adsorbent, Zhao et $a l^{4}$ reported the adsorbed molecules lay flat on active carbon surface and isotherms are all Langmuir type. Chang et $a l^{5,6}$ indicated a high adsorption capacity of $303 \mathrm{mg} \cdot \mathrm{g}^{-1}$ for PEG with an average MW of 6000 from copper electroplating solutions at 288-313 K. While a long equilibrium period of 14 days needed.

Activated carbons are the most widely used adsorbent in the removal or recovery of organic compounds from liquid-phase streams due to their large surface area and nearly non polar surface $^{7}$, they still present some disadvantages such as flammability, difficult to regenerate highboiling organics and promoting polymerization of some polymerizable mixtures.

Expanded graphite (EG) is a kind of new adsorbent; it can be prepared with chemical method or electrical chemical method. The pore in EG ranges from several nm to hundreds $\mu \mathrm{m}$ and it can be described using a 4-level model ${ }^{8}$. EG has been attracting attentions of scientists and engineers as an absorbent with a high adsorption capacity for organic materials, such as heavy oil and biomedical molecules ${ }^{9-14}$. The research group of Pang has studied the adsorption capacities of EG for oil, dyes, aromatic sulfonates ${ }^{15-17}$, results indicate EG show definite adsorption capability for these organic substances, especially for oils. Both adsorbate molecular weight and molecular structure affected sorption type, saturation adsorbance.

Contrast to the adsorption on activated carbon, basic study of PEG on EG is scarce. Therefore, aim of this work is to study the adsorption equilibrium and adsorption kinetics of EG for PEG with different MW in water solution and do further evaluation of applicability of common isotherm models (i.e., Langmuir and Freundlich) and pseudo-second-order rate model.

\section{Experimental}

EG is prepared according to literature ${ }^{18}$ and its pore distribution was detected by with Auto Pore II 9220 Mercury Porosimeter (Micromeritics Inc. USA) under the condition of 0.58 1301PSIA. Results given in Table 1 show pores in EG are mainly micron pore and the detected total pore area appear too higher than that of BET method ${ }^{19}$.

Table 1. Structural parameter of EG

\begin{tabular}{ccccccc}
\hline $\begin{array}{c}\text { Bulk density, } \\
\mathrm{g} / \mathrm{mL}\end{array}$ & $\begin{array}{c}\text { Total pore } \\
\text { area, } \mathrm{m}^{2} / \mathrm{g}\end{array}$ & $\begin{array}{c}\text { Total volume, } \\
\mathrm{cm}^{3} / \mathrm{g}\end{array}$ & \multicolumn{4}{c}{ Distribution of pore volume, $\mathrm{mL} / \mathrm{g}$} \\
\hline 0.0308 & 1044.99 & 30.11 & 1037 & $1037 \sim$ & $10072 \sim$ & $112689 \sim$ \\
$\mathrm{nm}$ & 1.3693 & 7.4544 & 15.8525 & 3.6583 \\
\hline
\end{tabular}

\section{Adsorbates characteristic}

Adsorbates used in experiment were PEG with different MW of 1000, 4000, 10000, 20000, respectively. Simulated PEG wastewaters were prepared by dissolving PEG in distilled deionized water at various concentrations. In quantitative analysis ${ }^{20,21}$, Dragendoff was used as colored reagent of PEG and absorbance of the colored complex (color reaction lasted $10 \mathrm{~min}$ ) was detected with T6 New Century UV spectrophotometry (Puxi Tongyong Instrument Limited Company of Beijing). Absorbance values were recorded at the wavelength for maximum absorbance $\left(\lambda_{\max }\right)$ (as listed in Table 2) and its solution was initially calibrated for concentration in terms of absorbance units.

Table 2. MW and maximum absorbance wavelength of PEG

\begin{tabular}{ccccc}
\hline PEG & 1000 & 4000 & 10000 & 20000 \\
\hline$\lambda_{\max ,} \mathrm{nm}$ & 512 & 508 & 512 & 510 \\
\hline
\end{tabular}




\section{Static adsorption of PEG}

$0.20 \mathrm{~g}$ of EG is mixed in different conical glass flasks with $100.0 \mathrm{~mL}$ solution at the desired PEG concentration, $\mathrm{pH}$ and ionic strength. $\mathrm{pH}$ was adjusted with dilute $\mathrm{HCl}$ or $\mathrm{NaOH}$ solutions and ionic strength was adjusted with $\mathrm{NaCl}$ or $\mathrm{Na}_{2} \mathrm{SO}_{4}$. Mass of $\mathrm{EG}$ to volume of solution was standardized as $M / V=0.200 / 0.1=2.0 \mathrm{~g} / \mathrm{L}$. PEG concentration changes were recorded with spectrophotometer at $\lambda_{\max }$ and adsorbance was determined according to equation (1):

$$
q_{e}=V\left(C_{0^{-}} C_{e}\right) / M
$$

$q_{e}$ Equilibrium adsorbance of adsorbate on EG; $\mathrm{mg} / \mathrm{g} ; \mathrm{C}_{0}$ Initial concentration of PEG in solution; $\mathrm{mg} / \mathrm{L}$; $\mathrm{C}$ Equilibrium concentration of $\mathrm{PEG}$ in solution; $\mathrm{mg} / \mathrm{L}$; V Volume of solution; L; M Mass of EG; $\mathrm{g}$.

\section{Adsorption kinetics of PEG}

Adsorption kinetics experiments were carried out using a HZS-D shaking water bath (Donglian Haerbin, China) with a shaking speed of $100 \mathrm{rpm} / \mathrm{min}$. A series of desired PEG concentration and fixed $100.0 \mathrm{~mL}$ were placed in vessels, where they were brought into contact with EG at $5{ }^{\circ} \mathrm{C}, 25{ }^{\circ} \mathrm{C}$ and $45^{\circ} \mathrm{C}$, respectively. Amount of PEG captured by EG at different time was determined as equation (2):

$$
q_{t}=V\left(C_{0^{-}} C_{t}\right) / M
$$

$q_{t}$ Accumulative adsorbance of adsorbate on EG at the moment of $\mathrm{t} ; \mathrm{mg} / \mathrm{g} ; \mathrm{C}_{\mathrm{t}}$ Concentration of PEG in solution at the moment of $\mathrm{t}$; $\mathrm{mg} / \mathrm{L}$;

\section{Results and Discussion}

\section{Investigation of adsorption isotherm and thermodynamic parameters}

Static adsorption capacities of EG for PEG $(1000,4000,10000,20000)$ were measured. Figure 1 illustrates a typical I type isotherm just as the adsorption of linear herring sperm DNA on EG ${ }^{9}$. The planar structure and large molecules of PEG might form certain kinds of conformation on the surface of EG, which might reduce the adsorbed sites and make the further adsorption difficult. As shown in Figure 1(b), adsorbance decreases with the increase of PEG MW. Similar result was obtained as the adsorption of active carbon for $\mathrm{PEG}^{4}$. But adsorption capability of EG is lower than that of active carbon, the results testify the sieve effect.

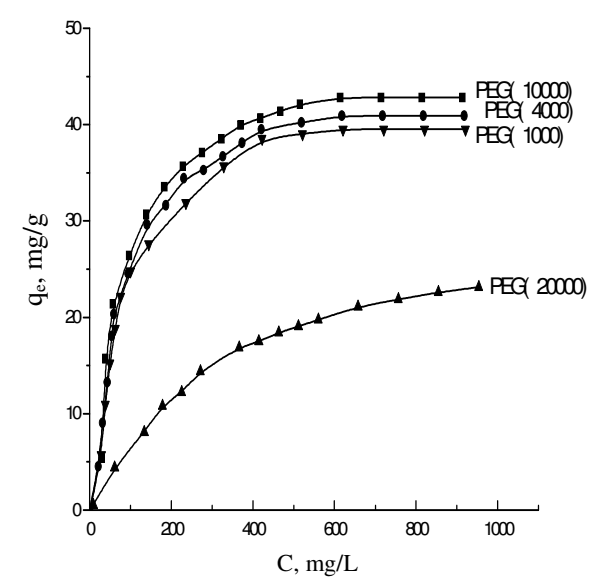

(a)

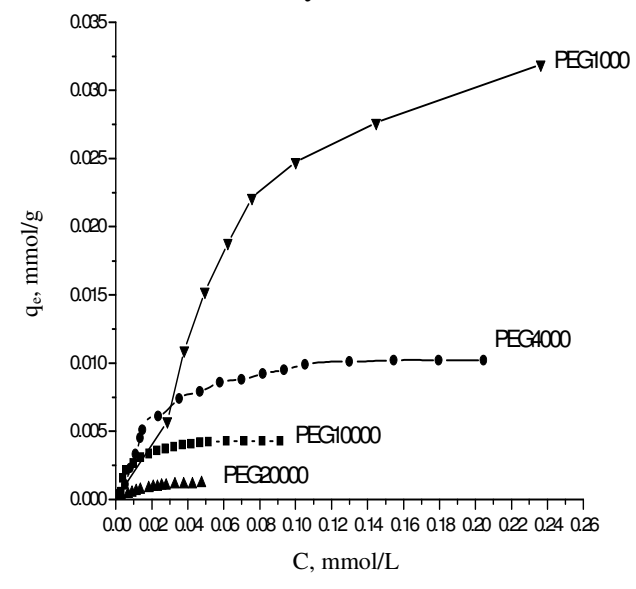

(b)

Figure 1. Adsorption isotherm of PEG $(1000,4000,10000,20000)$ at $25^{\circ} \mathrm{C}$, (a) Adsorbance is defined as $\mathrm{mg} / \mathrm{g}$; (b) Adsorbance is defined as $\mathrm{mmoL} / \mathrm{g}$ 
A considerable number of studies have been made on the polymer adsorption theory, providing a description of the polymer concentration and possible conformation in the interfacial region. For the adsorption of PEG on EG, Langmuir and Freundlich isotherm equations (3) and (4) were used to treat the isotherm data. The molecule area $(a)$ of PEG was calculated according to $q_{0}$ and total pore area as shown in Table 3.

$$
\begin{gathered}
\text { Langmuir equation }{ }^{22}: 1 / q_{e}=1 / q_{0}+A \cdot /\left(q_{0} \times C e\right) \\
\text { Freundlich equation: } \ln q_{e}=\ln K_{F}+(1 / n) \ln C e
\end{gathered}
$$

$q_{0}$ Maximum adsorption amount of PEG in forming complete monolayer coverage on EG pore surface; $\mathrm{mg} / \mathrm{g}, A$ Equilibrium concentration of PEG corresponding to half saturation adsorbance; $\mathrm{mg} / \mathrm{mL}, K_{F}$ Freundlich equation constant; $1 / n$ adsorption intensity for Freundlich equation.

\begin{tabular}{|c|c|c|c|c|c|c|c|}
\hline \multirow[b]{2}{*}{ MW } & \multicolumn{4}{|c|}{ Langmuir } & \multicolumn{3}{|c|}{ Freundlich } \\
\hline & $\frac{\mathrm{q}_{0}}{\mathrm{mmoL} / \mathrm{g}}$ & $\frac{\mathrm{a}}{\mathrm{nm}^{2} / \text { molecule }}$ & $\begin{array}{c}\mathrm{A} \\
\mathrm{mmoL} / \mathrm{mL}\end{array}$ & $\mathrm{r}$ & $\mathrm{K}_{\mathrm{F}}$ & $1 / \mathrm{n}$ & $r$ \\
\hline 1000 & 0.045 & 38.53 & 0.0837 & 0.9991 & 1.0945 & 0.4538 & 0.9846 \\
\hline 4000 & 0.012 & 144.5 & 0.0341 & 0.9995 & 11.1799 & 0.2078 & 0.9525 \\
\hline 10000 & 0.005 & 361.2 & 0.00988 & 0.9975 & 6.9114 & 0.2786 & 0.9567 \\
\hline 20000 & 0.001 & 1445 & 0.00628 & 0.9941 & 2.60833 & 0.4314 & 0.9056 \\
\hline
\end{tabular}

Table 3. Langmuir and Freundlich isotherm constants at $25^{\circ} \mathrm{C}$

${ }^{a}$ Area of PEG molecule, $(\mathrm{nm})^{2} /$ molecule; $r$ Linear related coefficient

As shown in Table 3, Langmuir isotherm gives a better fit than Freundlich isotherm. It's just the same as the adsorption of active carbon for PEG. There is an almost linear relationship between PEG MW and PEG molecule area (Figure 2). Results suggest PEG molecule lies flat on the EG surface ${ }^{4}$. PEG with high MW has a small A and strong appetency with EG.

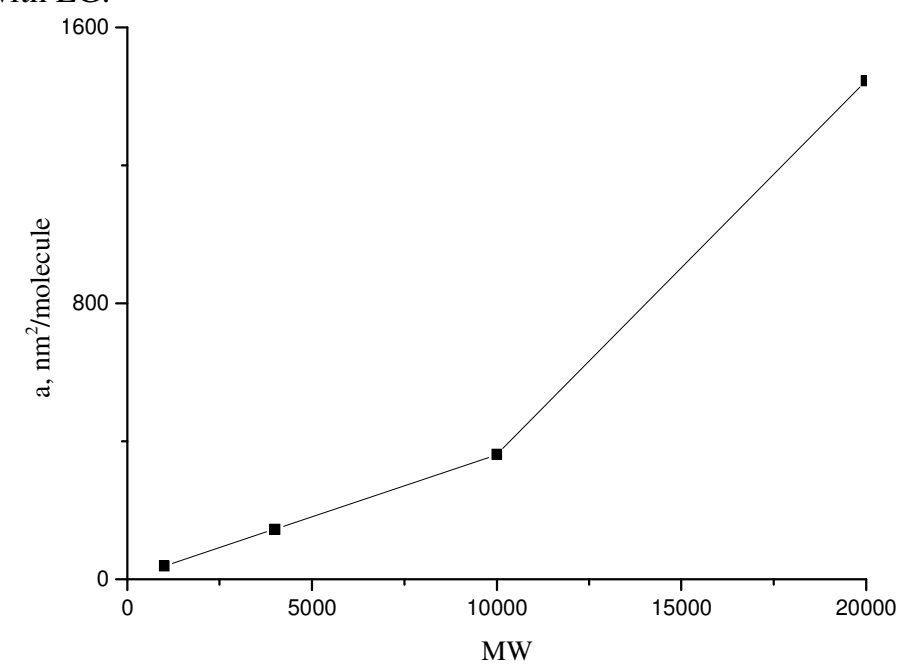

Figure 2. Relationship between PEG MW and molecule area

At the same time, adsorption free energy change $\left(\Delta G^{\circ}\right)$ of the adsorption process was calculated according to equation $(5)^{23}$, negative $\Delta G^{\circ}$ (Table 4) indicates that adsorption of these reference compounds on EG are all spontaneous. 


$$
\Delta G^{\circ}=\Delta R T \ln b
$$

$b$ Langmuire equation constant; $\Delta G^{\circ}$ Free energy change in the adsorption; kJ/moL.

Table 4. Adsorption constants and thermodynamic parameter of PEG

\begin{tabular}{ccccc}
\hline $\mathrm{PEG}$ & 1000 & 4000 & 10000 & 20000 \\
\hline$\Delta \mathrm{G}^{\circ} \mathrm{kJ} / \mathrm{moL}$ & -4.510 & -4.853 & -5.639 & -3.74 \\
\hline
\end{tabular}

Influence of ion strength on adsorption capacity

Influence of ion strength on adsorption capacity is investigated using a $100 \mathrm{mg} / \mathrm{L}$ PEG $(10000,20000)$ solutions which contain $\mathrm{NaCl}$ or $\mathrm{Na}_{2} \mathrm{SO}_{4}$ with concentration ranging from 0 to $50 \mathrm{mg} / \mathrm{L}$. The results are shown in Figure 3. It briefly indicates that the presence of $\mathrm{NaCl}, \mathrm{Na}_{2} \mathrm{SO}_{4}$ can improve the adsorption capacity of EG for PEG and the influence of $\mathrm{Na}_{2} \mathrm{SO}_{4}$ is more obvious than that of $\mathrm{NaCl}$. The results may be caused by the following reasons: the electrostatic interaction between PEG and adsorbent decreased with the increase in ionic strength for the suppression of the electric double layer ${ }^{24}$ and hydrophobic attraction of PEG increases due to the "salting-out" effect.

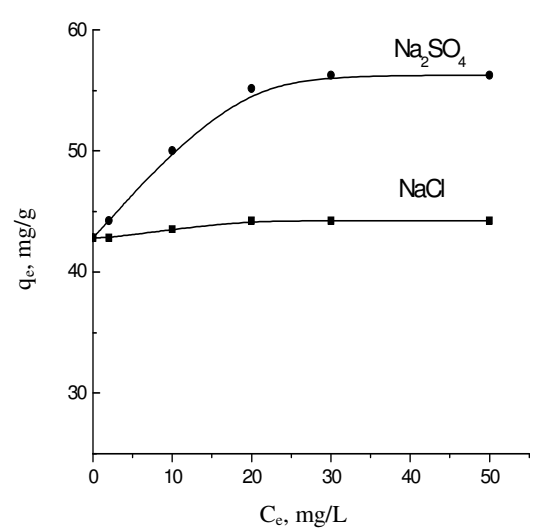

(a)

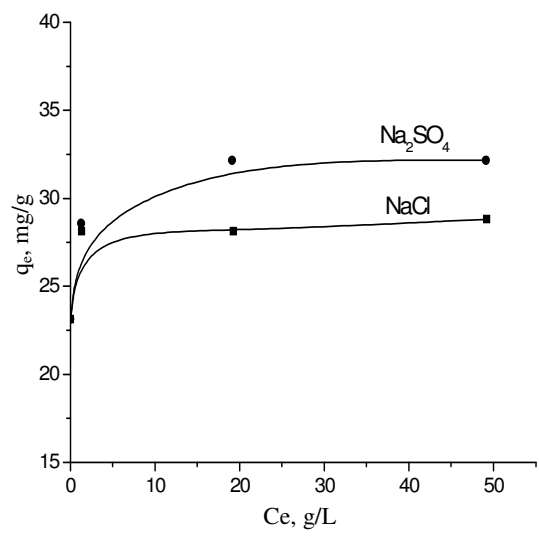

(b)

Figure 3. Influence of ion strength on adsorption capacity of EG for PEG (10000) (a), PEG (20000) (b) at $25^{\circ} \mathrm{C}$

\section{Influence of $\mathrm{pH}$ on absorbency and adsorption capacity}

$\mathrm{pH}$ of solution is adjusted with $\mathrm{HCl}$ or $\mathrm{NaOH}$. Investigation results show $\mathrm{pH}$ has no obvious influence on both PEG absorbency and adsorbance.

\section{Adsorption kinetic}

\section{Equilibrium time}

Influence of PEG (4000, 10000, 20000) concentration and temperature on adsorption equilibrium time was detected and shown in Figure 4-6. Results suggest that adsorbance is the function of PEG concentration, temperature and adsorption time. Adsorption rate increases with the increasing of temperature, which might be caused by the change of solution viscosity under different temperature. In kinetic experiment, different adsorption equilibrium times were used for different PEG under different temperature. 


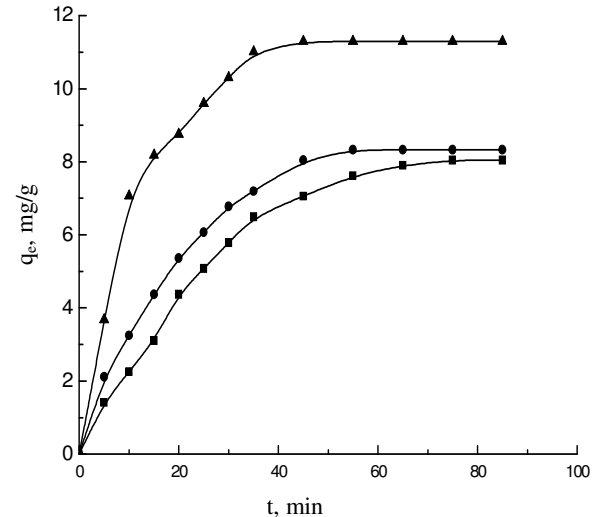

(a)

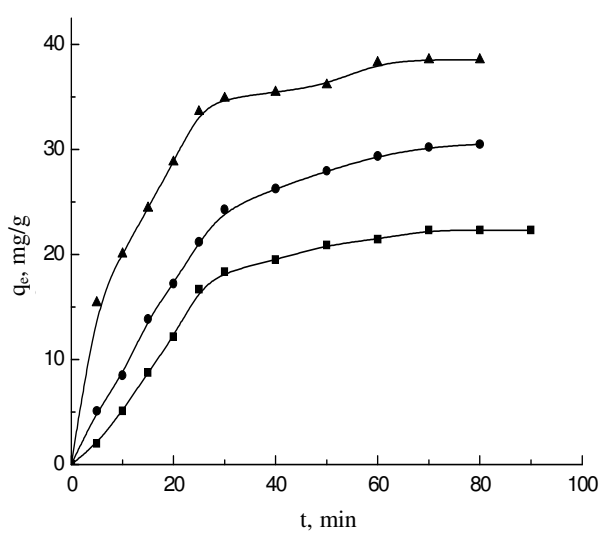

(b)

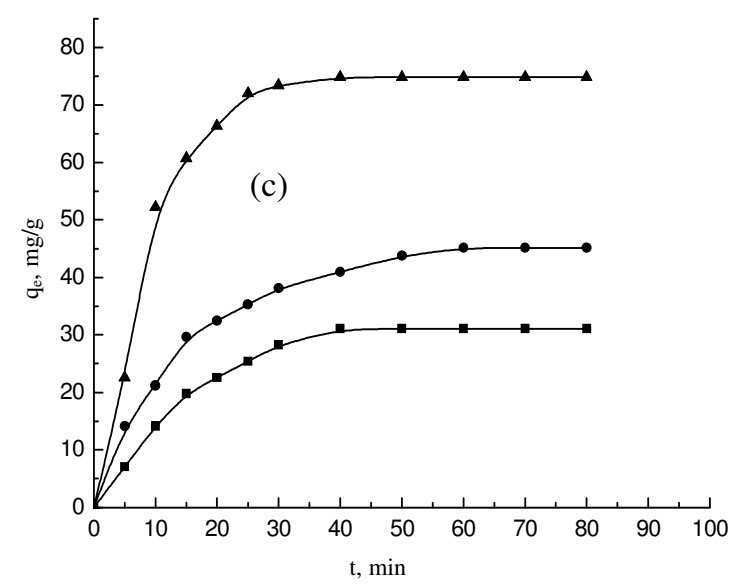

Figure 4. Influence of PEG (4000) concentration and temperature on adsorption kinetics. (a) $50 \mathrm{mg} / \mathrm{L}$, (b) $200 \mathrm{mg} / \mathrm{L}$, (c) $500 \mathrm{mg} / \mathrm{L}$; ( $) 5{ }^{\circ} \mathrm{C},(\bullet) 25{ }^{\circ} \mathrm{C},(\boldsymbol{\Delta}) 45^{\circ} \mathrm{C}$

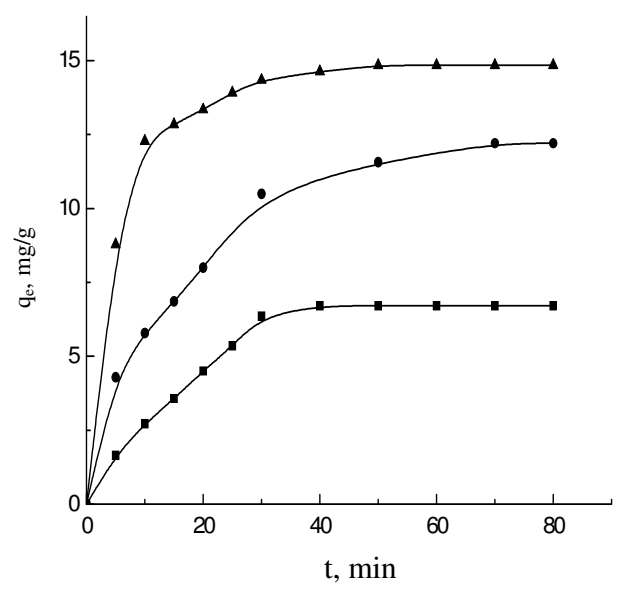

(a)

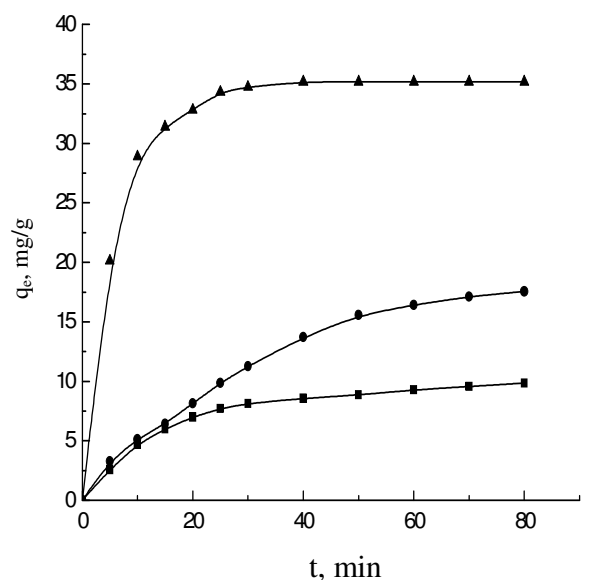

(b) 


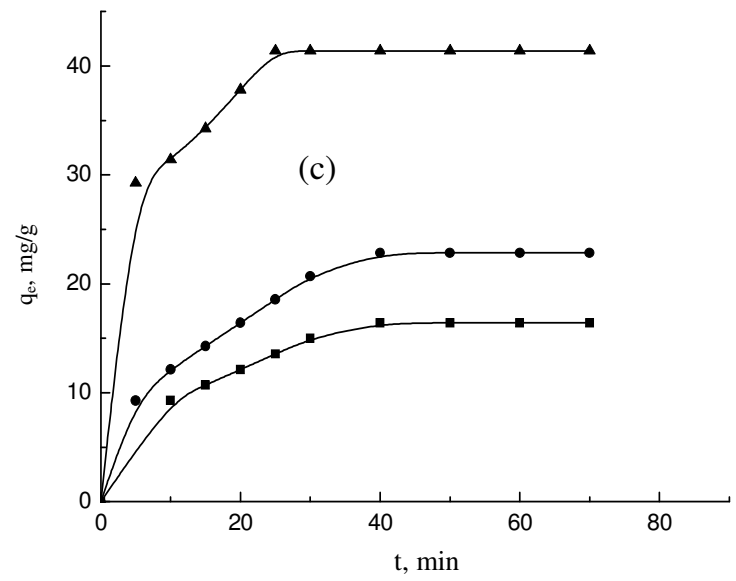

Figure 5. Influence of PEG (10000) concentration and temperature on adsorption kinetics.

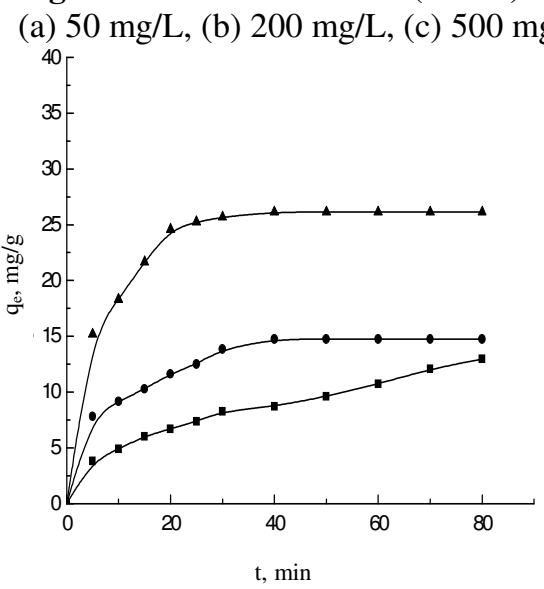

(a)

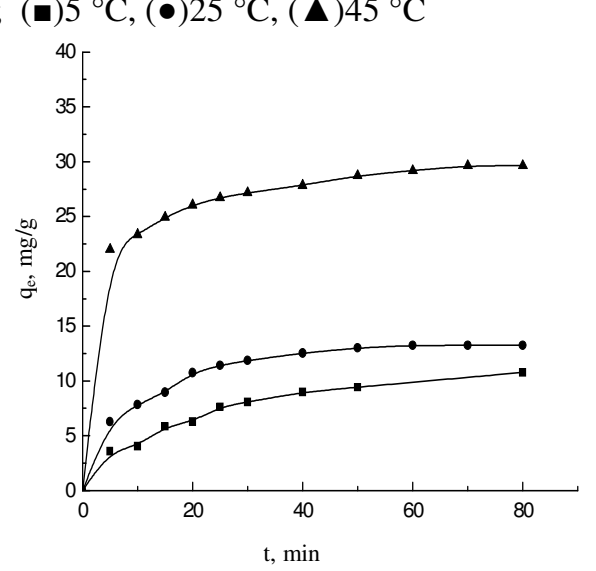

(b)

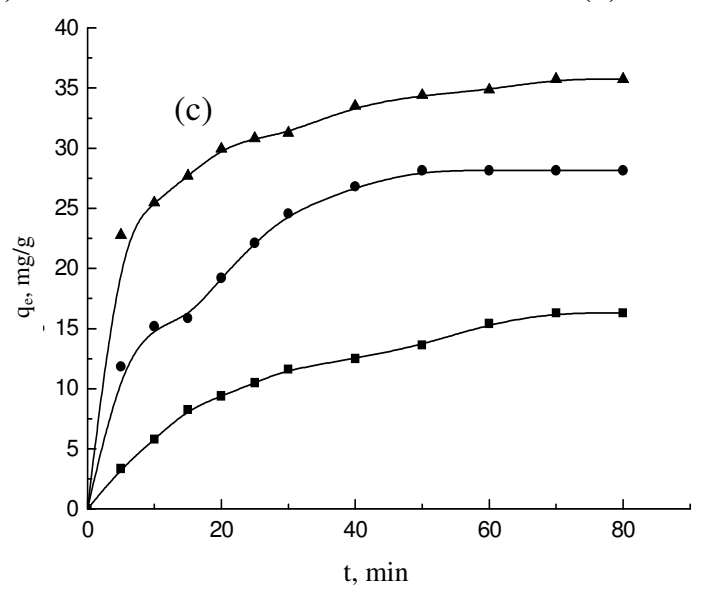

Figure 6. Influence of PEG (20000) concentration and temperature on adsorption kinetics. (a) $300 \mathrm{mg} / \mathrm{L}$, (b) $500 \mathrm{mg} / \mathrm{L}$, (c) $700 \mathrm{mg} / \mathrm{L}$; (•) $5{ }^{\circ} \mathrm{C},(\bullet) 25^{\circ} \mathrm{C},(\boldsymbol{\Delta}) 45^{\circ} \mathrm{C}$ 


\section{Adsorption kinetic models}

Both pseudo first and second order adsorption models were used to describe the adsorption kinetics data ${ }^{25}$. In both models, all the steps of adsorption such as external diffusion, internal diffusion and adsorption were lumped together and it is assumed that the difference between the average solid phase concentration and the equilibrium concentration is the driving force for adsorption and the complete adsorption rate is proportional to either the driving force (as in the pseudo first order equation) or the square of the driving force (as in the pseudo second order equation).

$$
\text { First-order model: } \ln \left(q_{e}-q\right)=\ln q_{e}-k t
$$

Second order model: $t / q=1 /\left(k q_{e}^{2}\right)+t / q_{e}$

$\mathrm{k}$ Adsorption rate constant $\left(\mathrm{min}^{-1}\right.$ for first order adsorption, $\mathrm{g} \cdot \mathrm{mg}^{-1} \cdot \mathrm{min}^{-1}$ for secondorder adsorption); $t$ Adsorption time (min)

Since $q$ reaches $q_{\mathrm{e}}$ at equilibrium, $q$ values smaller than $0.9 q_{\mathrm{e}}$ were used for analysis. Plots of $\ln \left(q_{\mathrm{e}}-q\right)$ versus $t$ and $t / q$ versus $t$ were used to test the first and second order models and the fitting results are given in Table 5-7. As for the line curve fit, second order model gives higher correlation coefficients than first order model. And $q_{\mathrm{e}, \mathrm{cal}}$ corresponding to second order model, agrees more well with experimental data except at $5{ }^{\circ} \mathrm{C}$ or lower PEG concentration. Thus, second order model is more suitable to describe the adsorption kinetics data. Similar results were observed in the adsorption of EG for Basic fuchsine and Auramine lake yellow $\mathrm{O}^{26}$ and zeolite for $\mathrm{PEG}^{13}$.

Table 5. Comparison of the adsorption kinetic models of PEG (4000) on EG

\begin{tabular}{|c|c|c|c|c|c|c|c|c|}
\hline \multirow{2}{*}{ ن } & \multirow{2}{*}{$\stackrel{0}{H}$} & \multirow{2}{*}{$\begin{array}{l}\mathrm{q}_{\mathrm{e}, \text { exp }}, \\
\mathrm{mg} / \mathrm{g}\end{array}$} & \multicolumn{3}{|c|}{ First order } & \multicolumn{3}{|c|}{ Second order } \\
\hline & & & $\mathrm{q}_{\mathrm{e}, \mathrm{cal}}, \mathrm{mg} / \mathrm{g}$ & $\mathrm{k}, 1 / \min$ & $\mathrm{r}$ & $\mathrm{q}_{\mathrm{e}, \mathrm{cal}}, \mathrm{mg} / \mathrm{g}$ & $\mathrm{k}, \mathrm{g} / \mathrm{mg} \cdot \min$ & $\mathrm{r}$ \\
\hline \multirow{3}{*}{50} & 5 & 046 & $7.51 \pm 1.04$ & $0.039 \pm 0.020$ & -0.996 & $11.92 \pm 0.332$ & $0.002 \pm 6.89 \mathrm{E}-05$ & 0.999 \\
\hline & 25 & 8.330 & $8.222 \pm 1.057$ & $0.051 \pm 0.002$ & -0.995 & 10.99 & $0.004 \pm 7.93 \mathrm{E}-05$ & 0.999 \\
\hline & 45 & 11.01 & $8.483 \pm 1.247$ & $0.065 \pm 0.016$ & -0.943 & $13.95 \pm 0.418$ & $0.006 \pm 1.76 \mathrm{E}-04$ & 0.998 \\
\hline \multirow{3}{*}{200} & 5 & 20.61 & $28.20 \pm 1.128$ & $0.047 \pm 0.005$ & -0.982 & $26.59 \pm 2.38$ & $0.001 \pm 1.33 \mathrm{E}-04$ & 0.996 \\
\hline & 25 & 31.62 & $39.67 \pm 1.112$ & $0.072 \pm 0.005$ & -0.990 & 37.38 & $0.002 \pm 4.55 \mathrm{E}-05$ & 0.999 \\
\hline & 45 & 39.24 & $32.55 \pm 1.201$ & $0.059 \pm 0.006$ & -0.974 & 44.66 & $0.002 \pm 7.15 \mathrm{E}-05$ & 0.999 \\
\hline \multirow{3}{*}{500} & 5 & 21.46 & $6.866 \pm 1.042$ & 0.0720 .002 & -0.999 & $22.05 \pm 3.2$ & $0.023 \pm 8.55 \mathrm{E}-05$ & 0.999 \\
\hline & 25 & 33.32 & $8.217 \pm 1.054$ & $0.059 \pm 0.003$ & -0.993 & $32.76 \pm 2.03$ & $0.024 \pm 4.34 \mathrm{E}-05$ & 1.000 \\
\hline & 45 & 37.83 & $20.38 \pm 1.227$ & $0.136 \pm 0.009$ & -0.988 & $40.65 \pm 0.361$ & $0.010 \pm 9.24 \mathrm{E}-05$ & 1.000 \\
\hline
\end{tabular}

Table 6. Comparison of the adsorption kinetic models of PEG (10000) on EG

\begin{tabular}{|c|c|c|c|c|c|c|c|c|}
\hline \multirow{2}{*}{$0 \stackrel{0}{\stackrel{d}{600}}$} & \multirow[b]{2}{*}{$\begin{array}{l}0 \\
0 \\
H\end{array}$} & \multirow[b]{2}{*}{$\begin{array}{l}\mathrm{q}_{\mathrm{e}, \mathrm{exp}} \\
\mathrm{mg} / \mathrm{g}\end{array}$} & \multicolumn{3}{|c|}{ First order } & \multicolumn{3}{|c|}{ Second order } \\
\hline & & & $\begin{array}{l}\mathrm{q}_{\mathrm{e}, \mathrm{cal}} \\
\mathrm{mg} / \mathrm{g}\end{array}$ & $\mathrm{k}, 1 / \mathrm{min}$ & $\mathrm{r}$ & $\mathrm{q}_{\mathrm{e}, \mathrm{cal}, \mathrm{mg} / \mathrm{g}}$ & $\begin{array}{c}\mathrm{k}, \\
\mathrm{g} /(\mathrm{mg} \cdot \mathrm{min})\end{array}$ & $\mathrm{r}$ \\
\hline \multirow{4}{*}{50} & 5 & 6.71 & $530 \pm 1.11$ & & -0.986 & 7.66 & $0.007 \pm 7.15 \mathrm{E}-04$ & 0.990 \\
\hline & 25 & 14.20 & $12.41 \pm 1.09$ & $0.039 \pm 0.003$ & -0.984 & $12.80 \pm 0.022$ & $0.012 \pm 2.07 \mathrm{E}-05$ & 1 \\
\hline & 45 & & $7.943 \pm$ & $0.089 \pm 0.020$ & -0.952 & 0.832 & $0.017 \pm 0.001$ & 0.997 \\
\hline & 5 & 11.28 & 1( & $0.044 \pm 0.002$ & -0.997 & .299 & $0.004 \pm 0.261$ & 0.999 \\
\hline \multirow[t]{3}{*}{200} & 25 & 17.56 & $17.38 \pm 1.038$ & $0.033 \pm 0.002$ & -0.993 & 0.296 & $0.003 \pm 0.421$ & 0.991 \\
\hline & 45 & 35.1 & $24.59 \pm 1.203$ & $0.121 \pm 0.014$ & -0.988 & $39.11 \pm 0.692$ & $0.007 \pm 1.15 \mathrm{E}-04$ & 0.999 \\
\hline & 5 & 21.41 & $20.59 \pm 1.175$ & $0.085 \pm 0.010$ & -0.983 & $25.08 \pm 1.571$ & $0.005 \pm 1.313$ & 0.995 \\
\hline \multirow[t]{2}{*}{500} & 25 & 39.97 & $15.90 \pm 1.072$ & $0.090 \pm 0.004$ & -0.989 & $39.15 \pm 1.813$ & $0.008 \pm 4.93 \mathrm{E}-04$ & 0.997 \\
\hline & 45 & 52.10 & $9.718 \pm 1.093$ & $0.070 \pm 0.008$ & -0.998 & $47.96 \pm 2.286$ & $0.0185 \pm 0.001$ & 0.999 \\
\hline
\end{tabular}


Table 7. Comparison of the adsorption kinetic models of PEG (20000) on EG

\begin{tabular}{|c|c|c|c|c|c|c|c|c|}
\hline \multirow{2}{*}{$\begin{array}{l}\underbrace{}_{00} \\
\stackrel{\Xi}{0} \\
ن\end{array}$} & \multirow{2}{*}{$\begin{array}{l}\cup \\
0 \\
\mapsto\end{array}$} & \multirow[b]{2}{*}{$\begin{array}{l}q_{e, \exp } \\
\mathrm{mg} / \mathrm{g}\end{array}$} & \multicolumn{3}{|c|}{ First order } & \multicolumn{3}{|c|}{ Second order } \\
\hline & & & $\begin{array}{c}q_{e, c a l} \\
(\mathrm{mg} / \mathrm{g})\end{array}$ & $\mathrm{k}, 1 / \mathrm{min}$ & $\mathrm{r}$ & $\begin{array}{c}q_{e, c a l} \\
(\mathrm{mg} / \mathrm{g})\end{array}$ & $\mathrm{k}(\mathrm{g} /(\mathrm{mg} \cdot \min ))$ & $\mathrm{r}$ \\
\hline \multirow{3}{*}{300} & 5 & 12.96 & & & & 62 & -04 & 0.993 \\
\hline & 25 & 14.75 & $9.700 \pm 1.066$ & $0.057 \pm 0.004$ & -0.993 & $16.77 \pm 0.942$ & $0.007 \pm 3.81 \mathrm{E}-04$ & 0.997 \\
\hline & 45 & 26.14 & $17.78 \pm 1.149$ & $0.090=$ & -0. & $29.16 \pm 0.537$ & $0.008 \pm 1.51 \mathrm{E}-04$ & 0.999 \\
\hline \multirow{3}{*}{500} & 5 & 10.78 & $9.863 \pm 1.044$ & $0.045 \pm$ & -0.9 & $13.56 \pm 0.294$ & $0.004 \pm 8.07 \mathrm{E}-05$ & 1 \\
\hline & 25 & 13.25 & $10.43 \pm 1.082$ & $0.068 \pm 0.004$ & -0.993 & $14.99 \pm 0.133$ & $0.008 \pm 7.51 \mathrm{E}-05$ & 1 \\
\hline & 45 & 29.64 & $10.10 \pm 1.041$ & $0.051 \pm 0.003$ & -0.997 & $29.45 \pm 0.380$ & $0.013 \pm 0.382081$ & 1 \\
\hline \multirow{3}{*}{700} & 5 & 16.31 & $14.22 \pm 1.046$ & $0.034 \pm 0.002$ & -0.994 & $18.93 \pm 0.466$ & $0.003 \pm 6.58 \mathrm{E}-05$ & 0.999 \\
\hline & 25 & 28.15 & $20.98 \pm 1.112$ & $0.047 \pm 0.006$ & 0.989 & $24.50 \pm 1.08$ & $0.007 \pm 1.02 \mathrm{E}-03$ & 0.999 \\
\hline & 45 & 35.75 & $15.75 \pm 1.069$ & $0.045 \pm 0.003$ & -0.989 & $33.81 \pm 0.184$ & $0.012 \pm 6.56 \mathrm{E}-05$ & 1 \\
\hline
\end{tabular}

Based on the second order model, initial adsorption rate and half-adsorption time were estimated according to equations (8) and (9):

$$
\begin{gathered}
u=k q_{e}{ }^{2} \\
t_{1 / 2}=1 /\left(k q_{e}\right)
\end{gathered}
$$

$u$ Initial adsorption rate, $\mathrm{mg} /(\mathrm{g} \cdot \mathrm{min}) ; t_{1 / 2}$ half-adsorption time (min).

Half-adsorption time $t_{1 / 2}$ is often used as a measure of the adsorption rate. As shown in Table 8-10, $u$ is found to increase with the increase of initial PEG $(4000,10000,20000)$ concentration and temperature and $t_{1 / 2}$ decrease with the increase of temperature. Secondorder rate constants are used to estimate activation energy of PEG adsorption on EG using Arrhenius equation ${ }^{27}$ :

$$
\operatorname{Lnk}=\operatorname{LnA}-E a /(R T)
$$

$A$ The re-exponential factor, $\left(\mathrm{g} \cdot \mathrm{mg}^{-1} \cdot \mathrm{min}^{-1}\right) ; E a$ Activation energy, $(\mathrm{kJ} / \mathrm{moL})$

Slope of lnk versus $1 / T$ is used to evaluate $E$ a, which is found less than 40.0 $\mathrm{kJ} \cdot \mathrm{mol}^{-1}$ (Table $8-10$ ). So, the adsorption is mainly physical adsorption. Similar results were observed in adsorption of EG for dyes of Basic fuchsine and Auramine lake yellow $\mathrm{O}^{26}$.

Table 8. Kinetic parameters for the second order adsorption model of PEG (4000)

\begin{tabular}{cccccc}
\hline $\mathrm{C}_{0}, \mathrm{mg} / \mathrm{g}$ & $\mathrm{T},{ }^{\circ} \mathrm{C}$ & $\begin{array}{c}\mathrm{u} \\
\mathrm{mg} / \mathrm{g} \cdot \min \end{array}$ & $\mathrm{t}_{1 / 2}, \min$ & $\begin{array}{c}\mathrm{E}_{\mathrm{a}}, \\
\mathrm{kJ} / \mathrm{moL}\end{array}$ & $\mathrm{r}$ \\
\hline \multirow{2}{*}{50} & 5 & 0.351 & 50.316 & & \\
& 25 & 0.528 & 27.442 & $16.08 \pm 2.31$ & 0.990 \\
& 45 & 1.139 & 15.511 & & \\
200 & 5 & 1.065 & 32.190 & & 0.967 \\
& 25 & 2.441 & 18.108 & $9.11 \pm 2.42$ & \\
& 45 & 4.911 & 10.351 & & \multirow{2}{*}{5} \\
& 5 & 2.345 & 27.100 & & \\
& 25 & 3.870 & 18.301 & $4.11 \pm 0.00$ & \\
\hline
\end{tabular}


Table 9. Kinetic parameters for the second order adsorption model of PEG (10000)

\begin{tabular}{cccccc}
\hline $\mathrm{C}_{0}, \mathrm{mg} / \mathrm{g}$ & $\mathrm{T},{ }^{\circ} \mathrm{C}$ & $\mathrm{u}, \mathrm{mg} / \mathrm{g} \cdot \min$ & $\mathrm{t}_{1 / 2}, \mathrm{~min}$ & $\mathrm{E}_{\mathrm{a}}, \mathrm{kJ} / \mathrm{moL}$ & $\mathrm{r}$ \\
\hline \multirow{5}{*}{50} & 5 & 0.409 & 21.406 & & \\
& 25 & 1.945 & 5.926 & $16.92 \pm 0.95$ & 0.998 \\
& 45 & 4.393 & 3.888 & & \\
200 & 5 & 0.749 & 19.764 & & \\
& 25 & 0.891 & 9.690 & $7.0 \pm 1.47$ & 0.979 \\
& 45 & 9.980 & 4.356 & & \\
500 & 5 & 1.159 & 9.905 & & \\
& 25 & 2.926 & 2.993 & $24.02 \pm 4.97$ & 0.979 \\
\hline
\end{tabular}

Table 10. Kinetic parameters for the second order adsorption model of PEG (20000)

\begin{tabular}{cccccc}
\hline $\mathrm{C}_{0}, \mathrm{mg} / \mathrm{g}$ & $\mathrm{T},{ }^{\circ} \mathrm{C}$ & $\mathrm{u}, \mathrm{mg} / \mathrm{g} \cdot \min$ & $\mathrm{t}_{1 / 2}, \min$ & $\mathrm{E}_{\mathrm{a},} \mathrm{kJ} / \mathrm{moL}$ & $\mathrm{r}$ \\
\hline \multirow{3}{*}{300} & 5 & 0.683 & 21.293 & & \\
& 25 & 1.908 & 9.999 & $15.20 \pm 4.02$ & 0.967 \\
& 45 & 6.976 & 4.664 & & \\
500 & 5 & 0.701 & 23.340 & & \\
& 25 & 1.906 & 8.900 & $22.03 \pm 2.61$ & 0.993 \\
& 45 & 11.128 & 2.629 & & \\
700 & 5 & 0.958 & 22.936 & & \\
& 25 & 4.331 & 5.657 & $28.02 \pm 3.95$ & 0.990 \\
& 45 & 13.759 & 2.324 & & \\
\hline
\end{tabular}

\section{Internal diffusion analysis}

Adsorption process on a porous adsorbent generally involves three stages: (i) external diffusion; (ii) internal diffusion (or intra-particle diffusion); (iii) actual adsorption ${ }^{23}$. Quantitative treatment of experimental data may reveal the predominant role of a particular step among the three that actually governs the adsorption rate. Adsorption step is usually very fast for the adsorption of organic compounds on porous adsorbents in comparison to the external or internal diffusion $\operatorname{step}^{27}$ and it is known that the adsorption equilibrium is reached within several minutes in the absence of internal diffusion ${ }^{28}$. Thus, the long adsorption equilibrium time of PEG on EG (40 180 min corresponding to adsorption temperature of $5 \sim 45{ }^{\circ} \mathrm{C}$ ) suggests that the internal diffusion may dominate the overall adsorption kinetics.

To provide definite information on the rate-limiting step, an internal diffusion model based on Fick's second law is used to test if the internal diffusion step is the rate-limiting step $^{23}$ :

$$
q=k_{i d} t^{1 / 2}
$$

$k_{\text {id }}$ Internal diffusion constant, $\mathrm{mg} /\left(\mathrm{g} \cdot \mathrm{min}^{1 / 2}\right)$.

According to the internal diffusion model, a plot of $q$ versus $t^{1 / 2}$ should give a straight line with a slope $k_{\text {id }}$ and an intercept of zero if the adsorption is limited by the internal diffusion process. The relationships between $q$ of PEG $(4000,10000,20000)$ and $t^{1 / 2}$ at different temperature are shown in Figure 7-9. In the range of the tested temperature, a linear relationship between $q$ versus $t^{1 / 2}$ with a zero intercept is found when the temperature is not high, which suggests internal diffusion step dominates the adsorption process before the equilibrium is reached. 


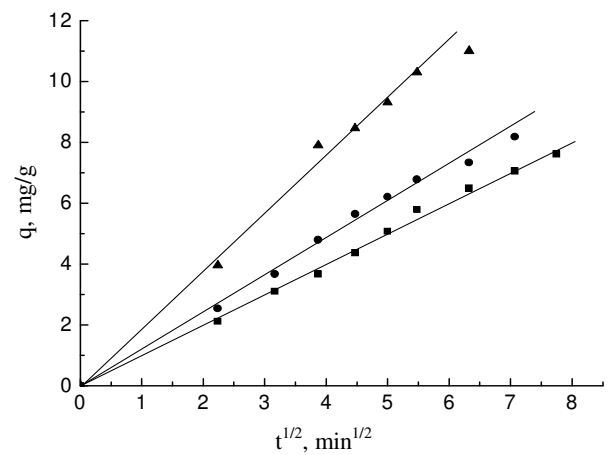

(a)

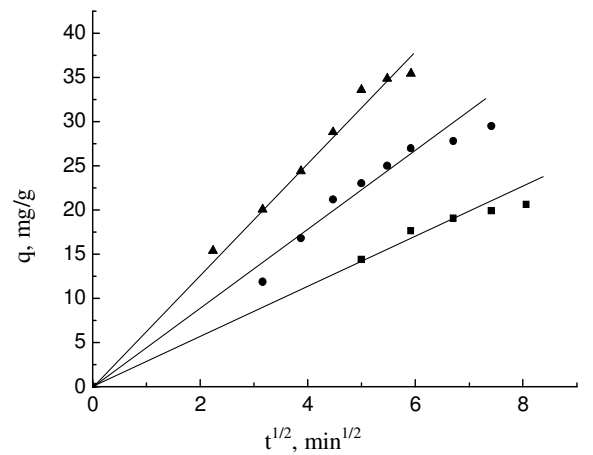

(b)

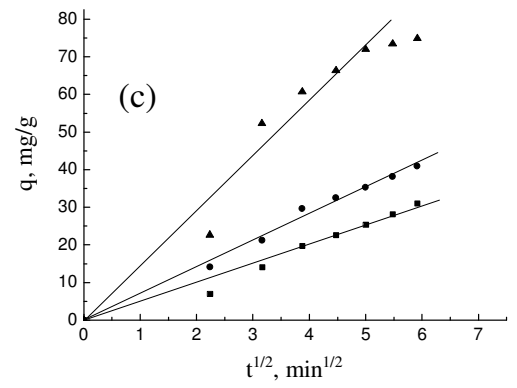

Figure 7. Plot of $q v$ s. $t^{1 / 2}$ in internal diffusion model of PEG (4000), (a) $50 \mathrm{mg} / \mathrm{L}$, (b) 200 $\mathrm{mg} / \mathrm{L},(\mathrm{C}) 500 \mathrm{mg} / \mathrm{L} ;(\bullet) 5^{\circ} \mathrm{C},(\bullet) 25^{\circ} \mathrm{C},(\boldsymbol{\Delta}) 45^{\circ} \mathrm{C}$

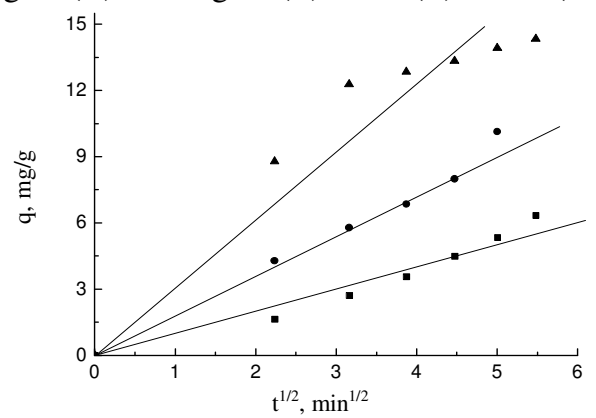

(a)

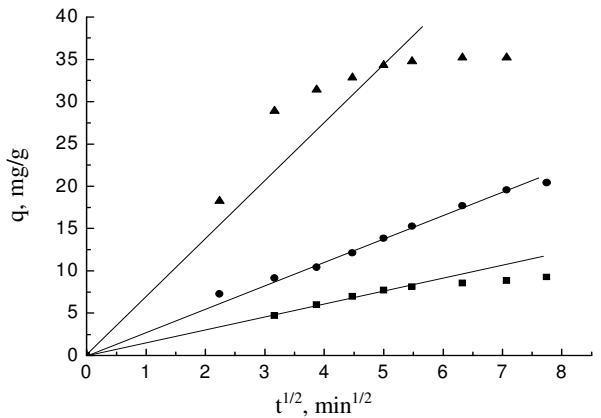

(b)

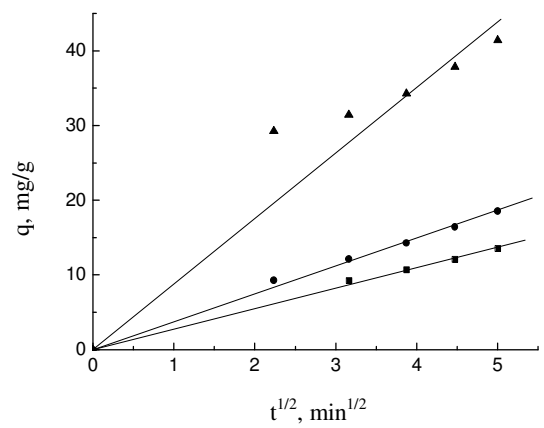

Figure 8. Plot of $q v$ s. $t^{1 / 2}$ in internal diffusion model of PEG (10000). (a) $50 \mathrm{mg} / \mathrm{L}$, (b) $200 \mathrm{mg} / \mathrm{L}$, (C) $500 \mathrm{mg} / \mathrm{L}$; (•) $5{ }^{\circ} \mathrm{C},(\bullet) 25^{\circ} \mathrm{C},(\boldsymbol{\Delta}) 45^{\circ} \mathrm{C}$ 


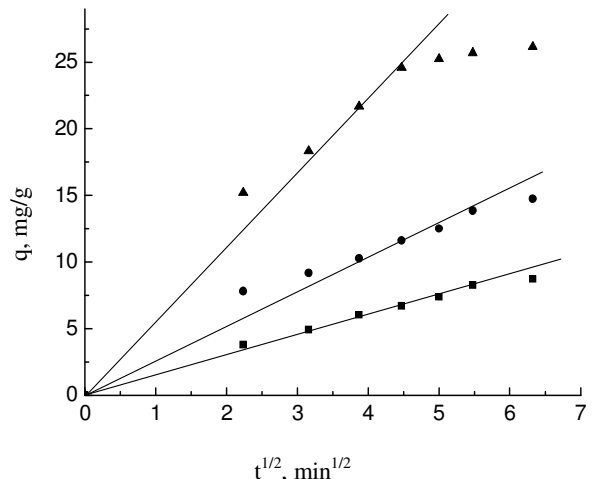

(a)

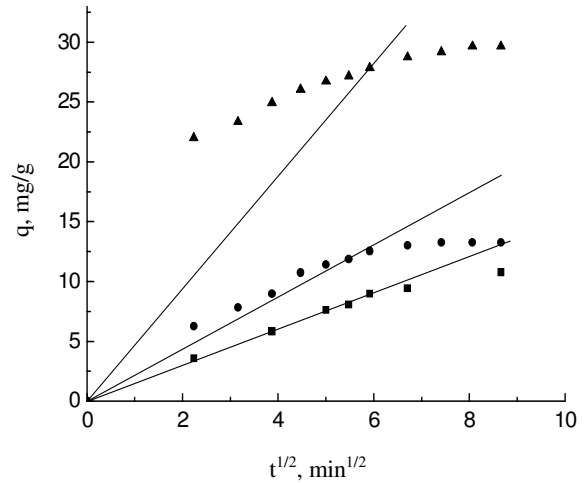

(b)

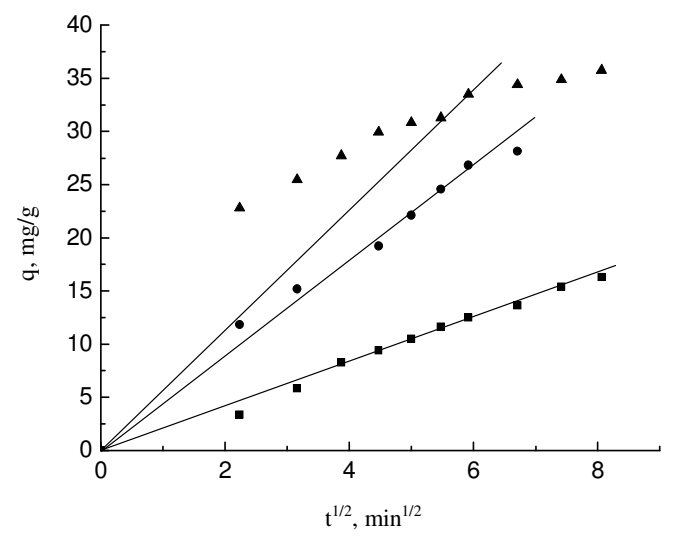

Figure 9. Plot of $q$ vs. $t^{1 / 2}$ in internal diffusion model of PEG (20000). (a) $300 \mathrm{mg} / \mathrm{L}$, (b) $500 \mathrm{mg} / \mathrm{LL}$, (C) $700 \mathrm{mg} / \mathrm{L} ;(\bullet) 5{ }^{\circ} \mathrm{C},(\bullet) 25{ }^{\circ} \mathrm{C},(\boldsymbol{\Delta}) 45^{\circ} \mathrm{C}$

\section{Conclusion}

Adsorption of EG for PEG with different MW has been investigated. The results are summarized as follows:

(1) The same as active carbon, adsorption isotherms of EG for PEG can be well described with Langmuir equation. But the adsorption equilibriums are faster than active carbon, and adsorption capacity of EG is lower than that of active carbon.

(2) Adsorption of EG for PEG is spontaneous, adsorption isotherm (1000, 4000, 10000, 20000) is type I, and PEG molecule lies flat on EG surface.

(3) Adsorption kinetics of EG for PEG can be described by pseudo-second-order model equation. Equilibrium time and half-adsorption time $t_{1 / 2}$ decreases with the increase of temperature. The adsorption belongs to physical adsorption, and internal diffusion is tested to be the rate-limiting step of the complete adsorption process.

\section{Acknowledgments}

This study was supported by Doctor Foundation of Hebei province Education Office (China, No.B2004402) and Doctor Foundation of Hebei University. We gratefully acknowledge their support during the study. 


\section{References}

1. Song C M, Zhuang X L, Xie M R and Zhang Y Q, Polym Mater Sci Eng., 2008, 24(1), 143.

2. Hou W Q and Huang L, Nat Sci J Xiangtan Univ., 1996, 18(1), 144.

3. Imamura S, Ind Eng Chem Res., 1999, 38, 1743.

4. Zhao Z G and Gu X R, Acta Phys Chim Sci., 1989, 5(2), 185.

5. Chang C F, Chang C Y, Tsai W T and Wu S C, J Coll Interf Sci., 2000, 232(1), 207-209.

6. Chang C Y, Tsai W T, Ing C H and Chang C F, J Coll Interf Sci., 2003, 260(2), 273-279.

7. Aggarwal D, Goyal M and Bansal R C, Carbon, 1999, 37, 1989-1997.

8. Zhao H, Zhou W, Shen W C and Kang F Y, Mater Sci Eng., 2002, 20(2), 153-156.

9. Kang F Y, Zheng Y P, Zhao H, Wang H N, Wang L N, Shen W C and Inagaki M, New Carbon Mater, 2003, 18(3), 161.

10. Toyoda M, Moriya K, Aizawa J I, Konno H and Michio I, Desalination, 2000, 128(3), 205.

11. Inagaki M, Konno H, Toyoda M, Moriya K and Kihara T, Desalination, 2000, 128(3), 213-218.

12. Inagaki M, Shibata K, Setou S, Toyoda M and Aizawa J , Desalination, 2000, 128(3), 219-222.

13. Toyoda M, Nishi Y, Iwashita N and Inagaki M, Desalination, 2003, 151(2), 139-144.

14. Inagaki M, Nagata T, Suwa T and Toyoda M, New Carbon Mater, 2006, 21(2), 97-102.

15. Pang X Y, Ren H L, Gong F and You T T, J Hebei Univ (Nat Sci)., 2008, 28(5), 512.

16. Pang X Y, Lv P, Feng Y Q and Liu X W, Environ Sci-An Indian J, 2008, 3(2), 150.

17. Pang X Y, Su Y J, Lv P, Ren H L and Gong F, J Hebei Univ (Nat Sci)., 2010, 30(1), 37.

18. Pang X Y, Dong Z Y and Li X L, Chinese Carbon, 2007, 2, 35.

19. Shen W C, Cao N Z, Wen S Z, Liu Y J, Liu Z X and Inagaki M, Carbon Tech., 1996, 3, 1.

20. Country Environ. Prot. Bureau, Environmental Protection Industry Standard's Republic of China HJ/T 271-2006-Specifications for Environmental Protection Product Ultrafiltration Equipment, 2006.

21. Wu Y, Niu H and Hu Q Y, J Hefei Univ (Nat Sci),, 2005, 15 (1), 19.

22. Shao Z H, Zhou M H and Lei L C, Acta Scientiae Circumstantiate, 2005, 25(5), 655.

23. Wu Z J, Hyeonwoo J and Kangteak L, Chem Eng J., 2005, 112, 227.

24. Chiou M S, Li and H Y, Chemosphere, 2003, 50(8), 1095.

25. Chiou M S, Li and HY, J Hazard Mater, 2002, 93(2), 233.

26. Pang X Y, Lv P, Gong F, Ren H L and Liang X H, Chem J Internet, 2007, 9(12), 53.

27. Sarkar M, Acharya P K and Bhattacharya B, J Colloid Interf Sci., 2003, 266(1), 28.

28. Mak S Y and Chen D H, Dyes Pigments, 2004, 61(1), 93. 


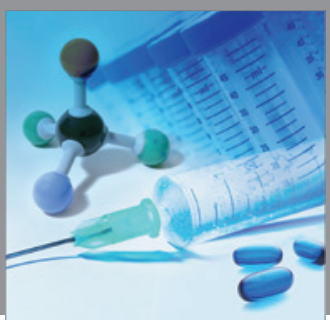

International Journal of

Medicinal Chemistry

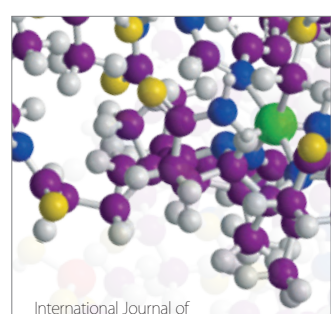

Carbohydrate Chemistry

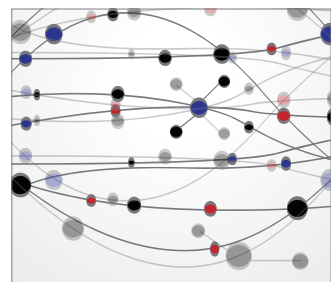

The Scientific World Journal
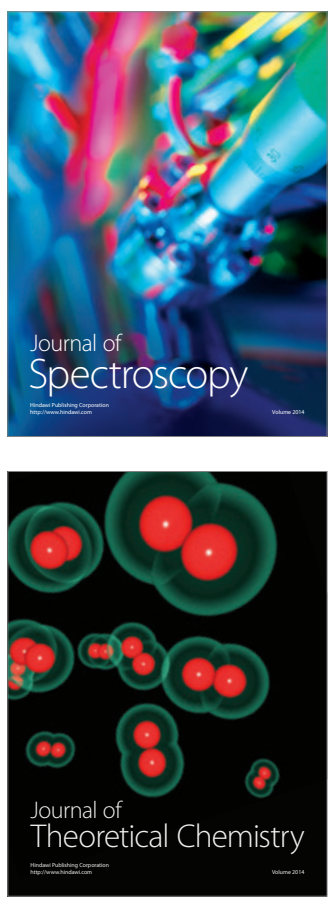
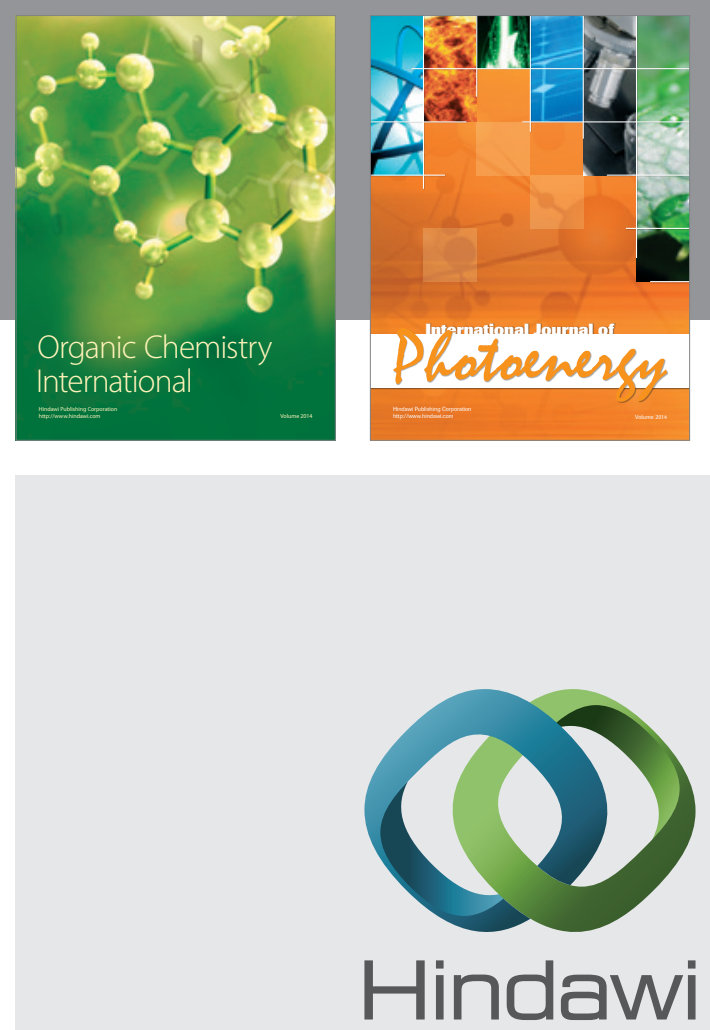

Submit your manuscripts at

http://www.hindawi.com
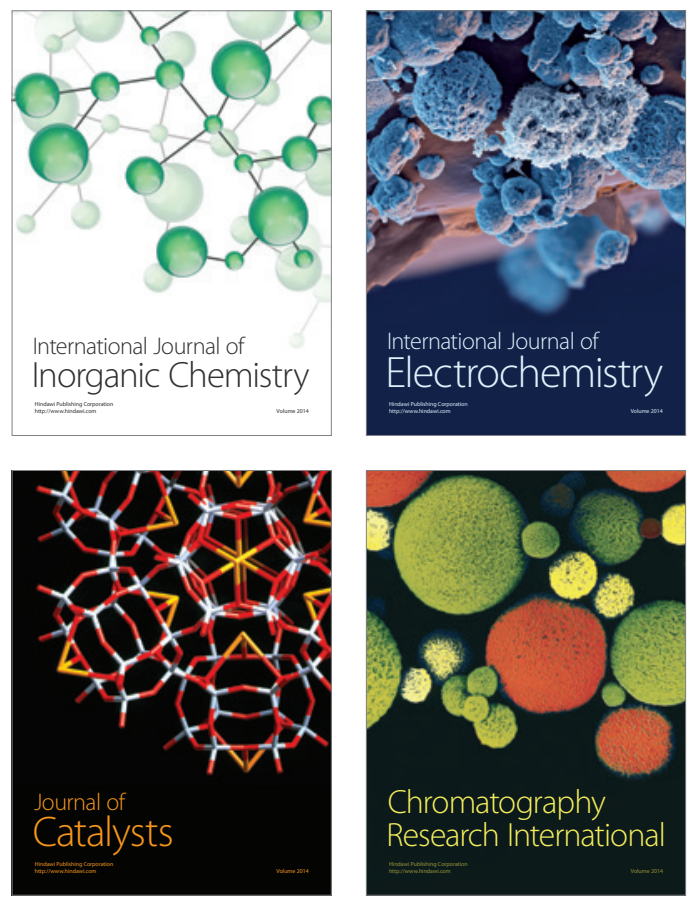
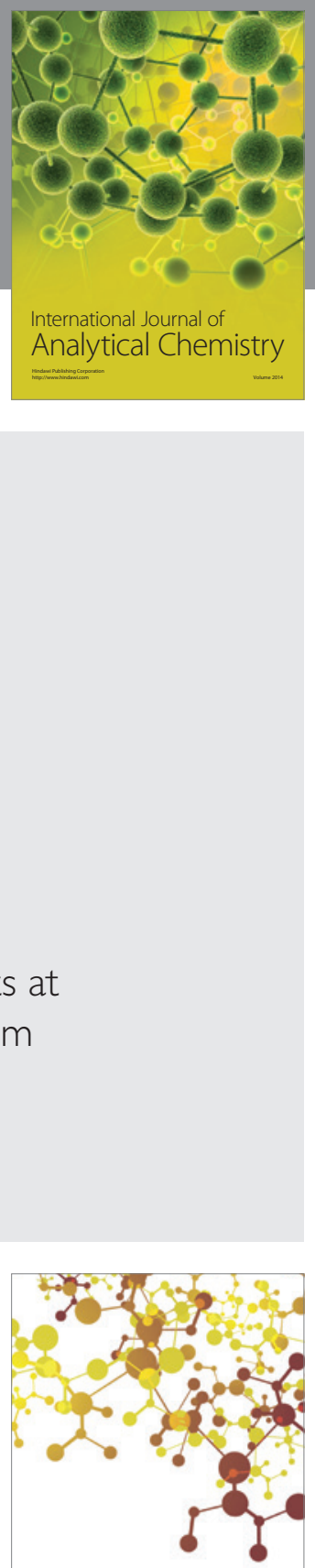

Journal of

Applied Chemistry
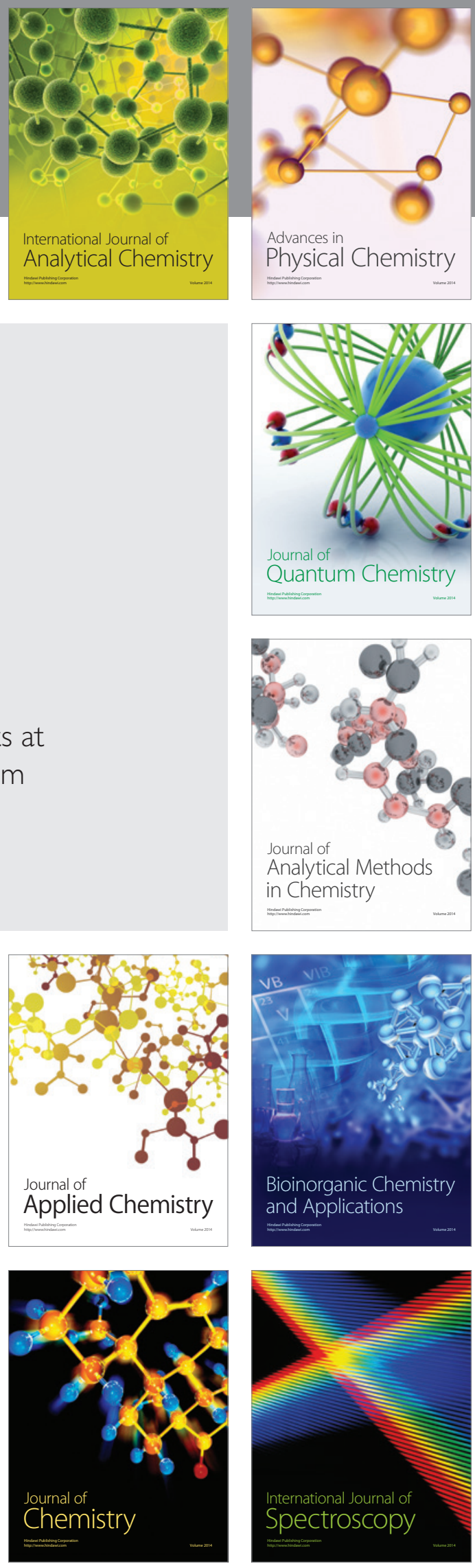